15. Modev S. Leadership in education - Bulgarian example in the context of good European practices. 2019. URL: https://library.iated.org/view/MODEV2019LEA (accessed: 26.02.2020)

\section{Prof. Mariela Modeva,}

Ph.D., Director, Institute for development and research of leadership

in the information environment, University of library research

and information technology, Member of the UNESCO Department of ICT,

cultural heritage and library research, Secretary General of ICOMOS (2011-2017),

Member of ICOMOS (Sofia, Bulgaria),m.modeva@unibit.bg

\section{Integration of migrants through education in Bulgaria: \\ interactivity in the learning process}

The purpose of the article is to introduce the reader to the theory and practice of applying specific didactic methods in the context of various problem situations as interactive forms of learning and their role in the integration of migrants in Bulgaria. Interactive techniques help to intensify the communication between students. All participants of the educational process are involved, no one remains a passive observer. The form of tasks requires lasersharp focus, activates memory, empathy, personal participation in solving the task and interaction between participants. Integration of migrants through educational innovations is the best way to organize their normal life in Bulgarian society. Actual examples provide an opportunity to apply best practices.

Keywords: integration of migrants, education, interactive methods, integration, migrants in Bulgaria, adaptation

\title{
Тамара Тюляева
}

\section{Тенденции развития и проблемные вопросы поликультурного образования в современном обществе}

Статья посвящена теоретическим аспектам современного поликультурного обра зования, концептуальным подходам к межкультурному диалогу в образовательной среде, практической реализации поликультурного воспитания в образовательных организациях. Обсуждается значение развития межкультурных коммуникаций как социального заказа, принципа и приоритета государственной политики, методы и сложности формирования специальных компетенций педагогов в сфере поликультурного образования.

Ключевые слова: поликультурное образование, культура, межкультурная коммуникация, поликультурный диалог, полиэтничность, духовность, воспитание, ценности, образовательная среда

В условиях современного меняющегося мира чрезвычайно актуальным становится формирование активной мобильной коммуникабельной личности, готовой к взаимодействию в многоэтнической поликультурной среде. Данная проблема не нова для педагогики России и зарубежья. Актуальна ли в России сейчас проблема межнационального поликультурного диалога в образовательном пространстве?

Глобализация охватывает все сферы

Тюляева Тамара Ивановна,

кандидат исторических наук,

доцент, ведущий специалист Центра историко-культурных исследований религии и межцивилизационных отношений Института социально-гуманитарного образования,

Московский педагогический государственный университет, tamarit@mail.ru жизни современных обществ, в том числе и нашего Отечества. Но, безусловно, мы не должны забывать об уникальности своей национальной культуры, нравственном воспитании молодого поколения и формировании у него на циональной гражданской и культурной идентичности. Наша страна - одно 
из самых многонациональных государств, на территории которого проживают около 200 этносов и этнических групп, представители всех мировых религий, различных этноконфессиональных сообществ, несколько цивилизационно-культурных и историко-культурных общностей. Кроме того, Россия - один из крупнейших мировых центров внутренней и внешней миграции. Эти потоки усложняют исторически сложившееся культурное многообразие российского общества в целом и отдельных регионов, в частности.

Однако помимо приобщения к родной культуре, культуре религий, системе образования необходимо формировать гражданина многонационального государства. В связи с этим перед российской педагогической наукой и педагогическим сообществом стоит задача формирования не только этнической идентичности, но и полиэтнической многокультурной идентичности.

Использование в системе школьного преподавания краеведческого, регионоведческого материала в изучении вопросов религии, культуры этносов - один из способов решения многих вопросов обучения и воспитания. «Понимание поликультурного образования неотрывно от духовно-нравственного воспитания и перспективно для гражданского образования» [8, с. 44].

Социализация современного человека происходит все в большей степени вне рамок национального государства, этноса, конфессии, общества, семьи. Благодаря прогрессу в сфере распространения информации человек оказывается один на один с огромным, противоречивым, полным опасностей миром. Единственным эффективным средством не потерять, а найти себя, сохранить национальную культурную самобытность является образование. Ответом государства на социальные вызовы стали три серьезных шага в духовно-нравственном воспитании обучающихся в общеобразовательных организациях Российской Федерации: разработка и принятие концепции духовно-нравственного развития и воспитания личности гражданина России [6], введение в учебный план школ комплексного учебного курса «Основы религиозных культур и светской этики» в 4-м классе (2009 - экспериментальный предмет, 2013 обязательный); предметной области в основной школе «Основы духовно-нравственной культуры народов России» (2015).

Дать молодым людям основы духовно-нравственного воспитания необходимо. Без опоры на традиции, устои, исторический опыт своего народа, без принятия ценностей предков нельзя стать культурным духовным человеком. «Но как не обратить благо во зло? Утрата своих корней, начиональной самобытности, родного языка, неприятие всего чужого перерастает в отчуждение, агрессию, экс тремизм - губительны для личности. Это путь к девальваиии начиональной, этнической, культурно-лингвистической уникальности. Сохранять патриотизм, свою культурно-этническую принадлежность, оставаясь гуманистом, человеком толерантнъм - важнейшее качество личности», - отмечает Е.Г. Артамонова [1, с. 7].

В многонациональной России должен происходить разумный процесс диалога культур, в результате которого молодежь - учащиеся и студенты - будут понимать ценность своей и уникальность другой культуры. По мнению А.Н. Иоффе, «Необходимо, итобъ учашиеся имели представление о спечифике территориального и государственного устройства странъ, проживающих в России народов и их культурном пространстве; понимали необходимость уважать культуру каждого народа и важность научиться жить в современном обществе, где люди не похожи друг на друга, имеют собственнъе объцаи, традиции» [9, с. 22-23].

«Предположим, что человек в течение всей своей жизни ни разу не выезжает за предель своей страны, и никогда 
не оказывается в чужой (иной) среде. Нужно ли сказать, ито межнациональный поликультурный диалог ему не нужен? Конечно же, нет, так как в межнациональном поликультурном диалоге речь идет не только о взаимодействии в многонаииональной среде. Речь о диалоге культур. Ведъ диалог культур - это прежде всего форма взаимодействия через личность-культуру» [5, с. 47]. М.М. Бахтин понимает культуру как форму общения людей разных культур, как форму диалога: для него культура там, где есть как минимум две культуры. Диалог преодолевает замкнутость и односторонность этих культур. При диалоговой встрече они не соединяются и не смешиваются, каждая сохраняет свое единство и целостность, но они взаимно обогащаются [2]. Таким образом, диалог культур, проведенный через призму межнационального, поликультурного в полной мере отвечает требованиям многокультурного общества и современного образования. Это комплексный разносторонний процесс социализации личности, основанный на преемственности культур, традиций, норм поведения [5, с. 49].

Культура - ресурс, созданный человечеством. В отличие от природных ресурсов, этот источник знаний, традиций, творчества надо не только щедро использовать и расходовать, но и восполнять. Культура воспроизводится и умножается только при условии ее интенсивного потребления. Начало этого потребления - детство. Недаром культура переводится с латинского как «выращивание», «воспитание».

ЮНЕСКО была выдвинута идея о взаимодействии культуры и образования, более того, включения культурного компонента в систему образования. Под эгидой этой организации международная конференция «Образование и культура» (1995) «определила духовный компонент наиболее значимым для сферы образования и культуру как совокупность идеалов, ценностей, веро- ваний, отношений между людьми, норм поведения, этикета, характерных для конкретной нации (этноса)» [5, с. 49]

Значимым научным результатом различных проектов, в том числе посвященных изучению процессов межнационального взаимодействия в полиэтнической образовательной среде, выступает модель поликультурного диалога, что позволяет формировать поликультурное мышление, бесконфликтное общение, безопасность личности, нравственные ценности и поступки, активно интегрироваться в мировое поликультурное пространство.

Овладение учащимися ценностями родной культуры делает их восприятие иных культур более точным, глубоким и всесторонним. Ноша культурных ценностей, писал академик Д.С. Лихачев, - «ноша особого рода. Она не утяжеляет наш шаг вперед, а облегчает. Чем большими иенностами мы овладеем, тем более изошренным и острым становится наше восприятие иных культур - культур удаленных от нас во времени и пространстве древних и других стран. Каждая культура иной странъ становится для интелли гентного человека "своей культурой», своей глубоко личной и своей в начиональном аспекте, ибо познание своего сопря жено с познанием чужого» $[11$, с. 13$]$.

Чтобы понять, принять культуру другого этноса, надо ее изучить. А для этого учащимся, студентам необходимо обратиться к представителю этноса, историю и культуру которого он изучает, построить с ним общение на основе диалога, уважения и соблюдения традиций, этикета, его культуры. Диалог культур может выступать как примиряющий фактор, предупреждающий возникновение конфликтов и войн. "Диалог - общение скультурой, реализачия и воспроизводство ее достижений, обнаружение иенностей иной культуры» [10]. Понятие диалога, применение диалоговых технологий (диспут, 
дискуссия, дебаты и пр.) в процессе обучения - проникновение в систему ценностей той или иной культуры, истории религии.

Как отмечают современные исследователи, «nоли культурное образование возникло как отклик на запрос соииальных групп этнических менъшинств в обеспечении гармоничного приобщения детей одновременно $u \kappa$ группе большинства, и к собственньм культурным традичиям» (14). Однако в последнее время признается эффективность поликультурного, межкультурного образования для всех обучающихся. Разные модели поликультурного образования становятся основой формирования общегражданской идентичности воспитанников во многих современных поликультурных обществах. В российском многонациональном обществе наблюдается рост культурного многообразия, борьба разных социальных групп за право на признание, национально-культурное и религиозное возрождение. Эти процессы амбивалентны: с одной стороны, у нас разрабатываются учебные программы [16], программы по адаптации соотечественников из-за рубежа и мигрантов, с другой - рост культурного многообразия порождает ксенофобию, стратификацию по религиозному или этноязыковому принципу, стремление «коренных» граждан дистанцироваться от зарубежных и внутренних трудовых мигрантов. Существует теория и практика поликультурного образования за рубежом [15, с. 146], которые предлагают педагогические и социальные результаты межкультурного образования.

Поликультурное образование призвано отвечать различным потребностям всех членов общества, независимо от их этической, культурной, социальной и религиозной принадлежности. При этом научные исследования проблем поликультурного образования выявили разные точки зрения ученых и педагогов на поликультурное образование. Как отмечают специалисты, поликультурное обучение и воспитание предназначено для повышения результативности образования [4].

Межкультурная коммуникаиия, или диалог культур это:

- совокупность разнообразных форм отношений и общения между индивидами и группами, принадлежащими разным культурам [14];

- общение людей, которые представляют разные культуры [17];

- связь и общение между представителями различных культур, что предполагает как непосредственные контакты между людьми и их общностями, так и опосредованные формы коммуникации (язык, речь, письменность, электронная общение) [7];

- особая социальность, новый всеобщий социум культуры, форма свободного общения людей в силовом поле диалога культур [3, с. 417];

- культурно обусловленный процесс, все составляющие которого находятся в тесной связи с культурной (национальной) принадлежностью участников процесса коммуникации [12, с. 35-36].

Мировое сообщество активно разрабатывает общую стратегию поликультурного воспитания и обучения. Эта проблема - постоянное столкновение мнений, позиций, культурных различий. Такая работа требует постоянного контроля со стороны педагога по формированию у обучающихся свободного мышления. И, конечно, постоянной работы над собой: ведь в любом случае цель поликультурного образования - создание психолого-педагогической, нравственной среды, способствующей межэтническому, межнациональному диалогу. Формирование готовности школьников и студентов к межнациональному поликультурному диалогу 
является составной частью личностно-ориентированного, системного и возрастного подхода в образовании, в основе которого лежит создание условий для полноценного формирования личностных качеств участников образовательного процесса [16, с. 15].

Т.В. Болотина и И.А. Мишина отмечают: «Российская школа как часть этого общества очевидно становится многокультурной образовательной организаиией в отношении всех участников образовательного прочесса. Поликультурное разнообразие учашихся в современной школе усиливает сочиальную неоднородность школьной средъ, заостряет проблему взаимоотношений и в связи с эти - проблему межэтнической и межличностной толерантности учашихся. В образовательный прочесс оказываются вовлеченныли представители разнъхх культурнъх общностей - иивилизачионно-культурных, этноначиональных, локально-территориальных, этнолингвистических, сочиокультурнъх, сочиальных и пр.» [4, с. 23].

В настоящее время невозможно решить эти проблемы без использования моделей поликультурного (межкультурного, интеркультурного, многокультурного) образования, важнейшим инструментом которого является интеграция условий, принципов, подходов межкультурной коммуникации (диалога культур) в образовательный процесс. Любая модель поликультурного образования требует наличия у педагога сформированных представлений об общих (гражданских, социальных, коммуникационных, общеучебных) и специальных (поликультурных, межкультурных, диалоговых) компетенций. Существуют профессиональный дефицит, обусловленный необходимостью переосмысления педагогами предшествующего опыта, необходимостью выработки новых качественных знаний и умений, а также тем, что тема межкультурной коммуникации находилась на периферии не только учебного процесса, но и педагогических исследований.
В 2014-2015 гг. сотрудники Академии повышения квалификации и профессиональной переподготовки работников образования провели научное исследование по теме «Формирование гражданской (общероссийской) и социальной компетенции педагогов, компетенций межкультурного взаимодействия, понимания поликультурного мира средствами исторического и обществоведческого образования». Его актуальность была обусловлена «требованиями государства к образованию как важнейшему институту сохранения и развития национальных культур и языков, инструменту культурной и политической интеграции российского общества недостаточной профессиональной компетентностью педагогов в области межкультурного взаимодействия и поликультурного образования, понимания и осмысления проблем поликультурного мира и России» [4, с. 26]. Исследователи выявили, систематизировали и описали современные подходы к организации моделей поликультурного образования в России, Европе, странах ближнего зарубежья, определили основные понятия, содержание и принципы поликультурности, межкультурной коммуникации, поликультурные и межкультурные компетентности, специальные умения и навыки педагогов в отношении детей-мигрантов, раскрыли особенности поликультурной образовательной организации и представили модель поликультурного образования.

Одним из условий успешного поликультурного образования и создания поликультурной образовательной среды, безусловно, является педагог, который владеет основами межкультурной коммуникации и взаимодействия, гражданскими, социальными компетенциями, пониманием поликультурности российского общества. Образовательная организация - школа, вуз - объективно должна выступать консолидирующим и даже системообразующим фактором как для этнического и эт- 
ноконфессионального большинства, так и для всего полиэтнического сообщества обучающихся, стать организацией внутришкольных и внутривузовских межэтнических межкультурных коммуникаций.

Таким образом, развитие той или иной модели поликультурного образования является важнейшим компонентом в российской государственной образовательной политике, социальным принципом и приоритетом.

\section{Лuтература:}

1. Артамонова Е.Г. К вопросу поликультурного воспитания молодежи в современном обществе // Развитие воспитательного пространства вуза в свете государственных требований к качеству профессионального образования: Сб. научн.-метод. материалов. Вып. ІІ. Сост. и науч. ред. Н.Ю. Синягина, Е.Г. Артамонова. М., 2014. C. 7-9.

2. Бахтин М.М. Эстетика словесного творчества. М.: Искусство, 1986. 445 с.

3. Библер В.С. От наукоучения - к логике культуры. М.: Политиздат, 1991. 413 с

4. Болотина Т.В., Мишина И.А. Сравнительный анализ организации поликультурного образования в странах дальнего и ближнего зарубежья как условие для создания модели «Формирование гражданской (общероссийской) и социальной компетенций межкультурного взаимодействия, понимания поликультурного мира и российского общества средствами исторического и обществоведческого образования» // Повышение квалификации педагогических кадров в изменяющемся образовании: Сб. материалов IV Всерос. научн.-практ. конф. (22 декабря 2015 г.). М.: ФГАОУ ДПО АПКиППРО, 2015. С. 21-26.

5. Геворкян М.М. Концептуальные подходы к межнациональному поликультурному диалогу в контексте поликультурного образования // Развитие воспитательного пространства вуза в свете государственных требований к качеству профессионального образования: Сборник научно-методических материалов. Вып. II. Сост. и науч. ред. Н.Ю. Синягина, Е.Г. Артамонова. М., 2014. С. 47-49.

6. Данилюк А.Я., Кондаков А.М., Тишков В.А. Концепция духовно-нравственного развития и воспитания личности гражданина России. М.: Просвещение, 2014. 24 с.

7. Денисова И.В., Еременко А.П. Типы межкультурных коммуникаций. URL: https:// docplayer.ru/36751908-Types-of-cross-cultural-communication.html (дата обращения: 23.05.2020)

8. Джуринский А.Н. Проблемы поликультурного воспитания в зарубежной педагогике // Вопросы философии. 2007. № 10. С. 41-52.

9. Иоффе А.Н. Воспитание толерантности и уважения к культурному многообразию // Преподавание истории в школе. 2009. № 4. С. 22-23.
10. Кокшаров Н.В. Взаимодействие культур: диалог культур // Культурная эволюция. 25.07.2006. URL: http://yarcenter.ru/articles/ethnicworld/dialog/vzaimodeystviekultur-dialog-kultur-557/ (дата обращения: 23.05.2020)

11. Лихачев Д.С. Письма о добром и прекрасном / Сост. и общая ред. Г.А. Дубровской. 3-е изд. М.: Дет. лит., 1989. 238 с.

12. Персикова Т.Н. Межкультурная коммуникация и корпоративная культура: учебное пособие. М.: Логос, 2007. 224 с.

13. Рассыпнова Р.И. Теория и практика поликультурного образования за рубежом. // Развитие воспитательного пространства вуза в свете государственных требований к качеству профессионального образования: Сб. научн.-метод. материалов. Вып. II. Сост. и науч. ред. Н.Ю. Синягина, Е.Г. Артамонова. М., 2014. С. 146-148.

14. Садохин А.П. Введение в теорию межкультурной коммуникации. М.: Высшая школа, 2005. 254 с

15. Тюляева Т.И. Духовно-нравственное образование в поликультурной среде: программа дополнительного педагогического образования. М.: АПКиППРО, 2012. 424 С.

16. Тюляева Т.И. Образование в поликультурном пространстве: Сборник научно-методологических и учебно-методических материалов. Saarbrusken, Deutschland.: LAP LAMBERT Academic Publishing, 2014. 472 c.

17. Фрик Т.Б. Основы теории межкультурной коммуникации: учебное пособие. Томск: Томский политехнический университет, 2013. 100 с.

\section{Tamara Tyulyaeva,}

Ph.D. in History, Associate professor, Leading specialist,

Center for historical and cultural studies of religion and intercivilizational relations,

Institute of Social and Humanitarian Education, Moscow Pedagogical State University, tamarit@mail.ru

\section{Development trends and problems of poli-cultural education in modern society}

The article is devoted to theoretical aspects of modern multicultural education, conceptua approaches to intercultural dialogue in the educational environment, and practical implementation of poli-cultural education in educational organizations. The article discusse the importance of the development of intercultural communications as a social order the principle and priority of state policy, methods and difficulties of forming special competencies of teachers in the field of poli-cultural education.

Keywords: poli-cultural education, culture, intercultural communication, intercultura dialogue, poli-ethnicity, spirituality, upbringing, values, educational environment 